\title{
AVAILABILITY DE OBRAS NO NETFLIX E DIREITOS AUTORAIS: COMPLEXIDADES DOS CONTRATOS MULTINÍVEL - PRODUÇÃO, TRANSMISSÃO E SINDYCATION
}

\author{
AVAILABILITY OF WORKS IN THE NETFLIX AND COPYRIGHT: \\ COMPLEXITIES OF MULTILEVEL CONTRACTS - \\ GENERATION, TRANSMISSION AND SINDYCATION
}

\author{
AVAILABILITY DE OBRAS EN NETFLIX Y DERECHOS DE AUTOR: \\ COMPLEJIDADES DE LOS CONTRATOS MULTINIVEL - \\ PRODUCCIÓN, TRANSMISIÓN Y SINDYCATION
}

\begin{abstract}
EWERTON RICARDO MESSIAS
http://orcid.org/0000-0002-9175-4865 / http://lattes.cnpq.br/1361703878121901 / ewerton_messias@hotmail.com Universidade de Marília - UNIMAR, Marília, São Paulo, Brasil.
\end{abstract}

\author{
JONATHAN BARROS VITA \\ https://orcid.org/0000-0002-3991-004X / http://lattes.cnpq.br/6200020135164378 / jbvita@gmail.com \\ Universidade de Marília - UNIMAR, Marília, São Paulo, Brasil.
}

\begin{abstract}
RESUMO
O presente artigo analisou, de maneira inédita, os possíveis desdobramentos jurídicos decorrentes dos contratos multinível firmados pela Netflix para o exercício de sua atividade econômica, mais especificamente os desdobramentos jurídicos relacionados à fixação de jurisdição internacional brasileira nas demandas decorrentes de invasões de conteúdos audiovisuais em relação a contratos de sindycation, e à possibilidade de existência de direitos autorais decorrentes da execução pública de obras audiovisuais. Foram investigados o availability de obras no Netflix, as regras para fixação de jurisdição internacional brasileira e as regras de cobrança de direitos autorais no direito brasileiro. 0 método de abordagem seguido foi o empírico-dialético, confrontando a forma como ocorre a availability de obras da Netflix com o disposto na legislação em vigor em território brasileiro. Conclui-se que a transmissão de conteúdos audiovisuais, por meio de SVoD por streaming da espécie webcasting interativo, revela-se como execução pública, realizada no âmbito do direito de comunicação pública, sendo lícita, a cobrança dos direitos autorais.
\end{abstract}

Palavras-chave: Availability; Contratos multinível; Direitos autorais.

\begin{abstract}
The present article analysed, in unpublished way, the possible legal ramifications resulting from the contracts multilevel secured by Netflix for the exercise of his economical activity, more specifically the legal ramifications made a list to the fixation of Brazilian international jurisdiction in the demands resulting from invasions of audiovisual contents regarding contracts of sindycation, and to the possibility of existence of copyright resulting from the public execution of audiovisual works. They were investigated the availability of works in the Netflix, the rules for fixation of Brazilian international jurisdiction and the rules of collection of copyright in the Brazilian right. The following approach method was the dialectic-empirical thing, confronting the form as it takes place to availability of works of the Netflix with the rule in the legislation in force in Brazilian territory. It is ended that the transmission of audiovisual contents, through SVoD for streaming of the sort webcasting interactive, reveals itself how public execution carried out in the context of the right of public communication, being lawful, the collection of the copyright.
\end{abstract}

Keywords: Availability; Contracts multilevel; Copyright 

COMPLEXIDADES DOS CONTRATOS MULTINIIVEL PRODUÇÃO, TRANSMISSÃO E SINDYCATION

\section{RESUMEN}

El presente artículo analizó de manera inédita los posibles desdoblamientos jurídicos derivados de los contratos multinivel firmados por la Netflix para el ejercicio de su actividad económica, más específicamente los desdoblamientos jurídicos relacionados a la fijación de jurisdicción internacional brasileña en las demandas derivadas de invasiones de contenidos audiovisuales en relación a contratos de sindycation, y a la posibilidad de existencia de derechos de autor derivados de la ejecución pública de obras audiovisuales. Se investigaron la availability de obras en Netflix, las reglas para la fijación de la jurisdicción internacional brasileña y las reglas de cobro de derechos de autor en el derecho brasileño. El método de abordaje seguido fue el empírico-dialéctico, confrontando la forma como ocurre la availability de obras de Netflix con lo dispuesto en la legislación vigente en territorio brasileño. Se concluye que la transmisión de contenidos audiovisuales, por medio de SVoD por streaming de la especie webcasting interactivo, se revela como ejecución pública, realizada en el ámbito del derecho de comunicación pública, siendo lícita, el cobro de los derechos de autor.

Palabras clave: Disponibilidad; Contratos multinivel; Derechos de autor.

\section{SUMÁRIO}

INTRODUÇAO; 1 AVAILABILITY DE OBRAS NO NETFLIX. 2 PRODUÇÃO DE OBRAS NO NETFLIX. 3 TRANSMISSÃO DE OBRAS DO NETFLIX. 4 CONTRATOS DE SINDYCATION NO NETFLIX. 5 JURISIDIÇÃO INTERNACIONAL FRENTE AS DEMANDAS DECORRENTES DOS CONTRATOS DE SINDYCATION DO NETFLIX. 6 DIREITOS AUTORAIS; CONCLUSÃO; REFERÊNCIAS.

\section{INTRODUÇÃO}

Os impactos ocasionados pelo crescimento tecnológico, principalmente durante os séculos XX e XXI, causaram e vêm causando inúmeras implicações positivas e negativas na sociedade, cujos efeitos transfronteiriços foram e vem sendo experimentados em nível mundial.

$\mathrm{Na}$ pós-modernidade, com a modernização dos meios de comunicação, proporcionada pela internet, as demandas litigiosas de natureza internacional cresceram exponencialmente, como exemplo, podem-se citar as demandas litigiosas derivadas dos contratos de sindycation de conteúdos audiovisuais firmados entre a Netflix e os estúdios de produção, e as demandas concernentes a eventuais direitos autorais decorrentes da transmissão de conteúdos audiovisuais com emprego de plataforma SVoD, por meio de streaming da espécie webcasting interativo, pela Netflix.

Neste contexto, inicialmente a presente pesquisa busca analisar em qual âmbito de atuação econômica atua a Netflix e, a partir daí, verificar como a Netflix identifica as demandas de seus clientes e como se dão as produções dos conteúdos audiovisuais que disponibiliza.

Em seguida, realiza-se um estudo acerca do produto disponibilizado pela Netflix, visando verificar se ele se trata de um produto de massa ou de um produto individual, 

COMPLEXIDADES DOS CONTRATOS MULTINIVEL PRODUÇÃO, TRANSMISSÃO E SINDYCATION

analisando-se, também, como se dá e quais as limitações referentes às transmissões de conteúdos audiovisuais aos clientes da Netflix.

Mais adiante, desenvolve-se uma análise específica sobre as demandas litigiosas derivadas dos contratos de sindycation de conteúdos audiovisuais firmados entre a Netflix e os estúdios de produção, visando verificar quais os limites da jurisdição internacional brasileira em relação aos casos de invasão de conteúdos audiovisuais por assinantes do Netflix.

Por fim, é verificado se a disponibilização pública de conteúdos audiovisuais, realizada pela Netflix, sujeita-se ao pagamento de direitos autorais aos autores ou coautores, podendo, a empresa, ser demandada por entidades representativas de classe em face de direitos autorais.

A justificativa para a pesquisa do tema em tela é o seu ineditismo e a necessidade de discussão acerca das repercussões jurídicas oriundas dos contratos multinível formados no âmbito da atividade econômica de transmissão de conteúdos audiovisuais pela internet explorada pela Netflix.

Quanto ao objetivo a ser alcançado, trata-se de uma tentativa de clarificar os possíveis desdobramentos jurídicos decorrentes do availabilty de obras do Netflix por meio de contratos multiníveis firmados pela Netflix para o exercício de sua atividade econômica, mais especificamente os desdobramentos jurídicos relacionados à fixação de jurisdição internacional brasileira nas demandas decorrentes de invasões de conteúdos audiovisuais em relação a contratos de sindycation, e aos eventuais direitos autorais decorrentes da execução pública de obras audiovisuais.

A despeito da suma importância da matéria abordada, o tema ainda carece de pesquisa aprofundada sob o prisma que ora se pretende focalizar, lacuna esta que, ao ser preenchida, certamente trará auxílio doutrinário ao intérprete e ao aplicador do Direito, contribuindo para que as normas jurídicas infraconstitucionais, relacionadas a tal temática, possam ser aplicadas de forma mais eficaz e em consonância com as normas constitucionais.

Para a obtenção dos resultados almejados pela pesquisa, o método de abordagem seguido é o empírico-dialético ${ }^{1}$, confrontando a availability de obras da Netflix, por meio de contratos multinível, com a legislação brasileira em vigor. Desta forma, durante a pesquisa analisou-se como ocorre a availability de obras da Netflix e quais as obrigações e deveres

\footnotetext{
10 método empírico-dialético consiste na confrontação entre a conduta fenomenalizada (empírico) e as normas logicamente estruturadas (regra jurídica). Para Lourival Vilanova, "os objetos culturais, entre os quais se aloja o direito, são todos aqueles que estão na experiência, tendo existência real, contudo sempre valiosos, positiva ou negativamente. 0 ato gnosiológico próprio é a "compreensão" e o método da correspondente ciência é o "empírico-dialético"”. VILANOVA, Lourival. Fundamentos do Estado de Direito. In: Escritos Jurídicos e Filosóficos, vol. I. São Paulo: IBET/Axis-Mundi, 2008.
} 

COMPLEXIDADES DOS CONTRATOS MULTINIVEL PRODUÇÃO, TRANSMISSÃO E SINDYCATION

decorrentes de tal atividade econômica em relação às relações de consumo, aos direitos autorais, ao marco civil da internet e às regras civis de fixação competência jurisdicional. Para tanto, foram utilizadas pesquisas bibliográfica, legislativa e jurisprudencial.

\section{AVAILABILITY DE OBRAS NO NETFLIX}

A Netflix é a mais visível plataforma de vídeo sob demanda - vídeo on demand - VoD por meio de streaming ${ }^{2}$, da espécie webcasting ${ }^{3}$ interativo, da atualidade.

$\mathrm{Na}$ verdade, a Netflix revela-se, mais especificamente, como uma plataforma subscription vídeo on demand - SVoD -, pois se trata de um serviço por assinatura, em que o usuário faz um pagamento periódico para ter acesso a um catálogo de conteúdos audiovisuais, os quais são licenciados para a plataforma mediante pagamento aos titulares (produtores).

Todo o acervo audiovisual da Netflix é acessado sob demanda, ou seja, não há uma grade de horários para transmissão, o conteúdo começa a ser reproduzido logo que o usuário desejar e pode ser pausado para ser assistido em outro momento ou lugar, pois, por estar presente em diversas plataformas tecnológicas, como smartTVs, smartphones e tablets, e ser transmitido por meio de streaming, é possível pausá-lo em um dispositivo e dar continuidade em outro, no mesmo ponto em que parou. O acervo audiovisual da Netflix também pode ser assistido na TV comum, por meio de aparelhos que se conectam a internet, como os videogames Playstation e Xbox, o Chromecast ${ }^{4}$, o Apple TV ${ }^{5}$ e os aparelhos de Blu-ray.

O usuário pode assistir os conteúdos do acervo audiovisual quando quiser, de onde quiser, por meio da plataforma tecnológica que quiser, desde que tenha instalado o aplicativo, e de onde parou.

\footnotetext{
2 Serviço de transmissão de dados via internet, de modo contínuo, que permite trafegar, como no caso da Netflix, os títulos de audiovisual sem a necessidade de armazenar o conteúdo no aparelho eletrônico do assinante. A tecnologia de streaming permite a transferência de conteúdos audiovisuais em tempo real sem que o usuário conserve uma cópia do arquivo digital em seu computador.

${ }^{3}$ Ocorre quando o conteúdo é disponibilizado apenas pela web. 0 grande exemplo de webcasting de conteúdo audiovisual é a Netflix, pois funciona apenas na internet. Tecnicamente, não se trata de TV, vez que não transmite a sua programação por meio por meio de ondas radioelétricas; sinais de satélite; fio, cabo ou outro condutor; meios óticos ou qualquer outro processo eletromagnético, mas sim por meio da internet. 0 webcasting pode ser interativo ou não interativo. A Netflix é um serviço de webcasting interativo porque o usuário pode escolher o conteúdo audiovisual que irá assistir.

${ }^{4}$ Aparelho desenvolvido pelo Google, no formato de um pendrive, que conectado à porta HDMI de uma TV comum a transforma em uma smartTV.

${ }^{5}$ Aparelho desenvolvido pela Apple, que por meio de um cabo se conecta à porta HDMI de uma TV comum a transforma em uma smartTV.
} 

COMPLEXIDADES DOS CONTRATOS MULTINIVEL PRODUÇÃO, TRANSMISSÃO E SINDYCATION

O serviço é disponibilizado apenas para assinantes, os quais, desde que estejam conectados à internet e possuam o aplicativo, podem acessar filmes, documentários, desenhos e shows, entre diversos outros gêneros de conteúdo audiovisual (exceto filmes eróticos), organizados em sistemas de indexação por listas e sugestões.

0 mercado de VoD encontra-se em plena ascensão e a Netflix, com seu serviço organizado como um catálogo de filmes e séries oferecidos por meio de assinatura, é apenas um dos inúmeros players e modelos de negócio que operam no Brasil ${ }^{6}$.

Como exemplo de outros players no mercado de VoD, pode-se citar o Telecine ${ }^{7}$, com o Telecine On, o qual oferece aos clientes aluguéis de filmes recentes em pay per view, e o Telecine Play, o qual oferece aos clientes acesso aos filmes em exibição no momento nos canais da rede; o Now, da Net; e a Looke ${ }^{8}$, da empresa de tecnologia Encripta9 .

A Availability de obras da Netflix é caracterizado por uma multiplicidade de caminhos, envolvendo contratos multinível ${ }^{10}$. Ou seja, a disponibilidade de obras da Netflix é caracterizada por contratos multinível, os quais abrangem múltiplas atividades econômicas ligadas à produção,

\footnotetext{
${ }^{6}$ STIVALETTI, Thiago; LEITÃO, Gustavo. Novos caminhos do VoD - Explosão do video sob demanda no país amplia modelos de negócios e atrai competidores para as novas plataformas. Movimento também faz produtores repensarem suas estratégias de lançamento. Revista Filme B +, mar. 2016, p.18.

7 O Telecine possui cerca de 1,5 mil títulos no mercado VoD no total. STIVALETTI, Thiago; LEITÃO, Gustavo. Novos caminhos do VoD - Explosão do video sob demanda no país amplia modelos de negócios e atrai competidores para as novas plataformas. Movimento também faz produtores repensarem suas estratégias de lançamento. Revista Filme B +, mar. 2016, p.18.

${ }^{8}$ A Looke, que começou a operar em setembro de 2015, sem muito alarde. São cerca de nove mil títulos, entre filmes, séries, shows e programas, em sistema misto: por assinatura (R\$ 18,90 para acesso em três telas diferentes) ou transacional (locações de R\$ 3,90 a R\$ 9,90, além de vendas para download). Iniciativa da empresa de tecnologia Encripta, a plataforma surgiu como sucessora do extinto comércio digital do grupo Saraiva. Hoje, são 800 mil cadastrados (o número de assinantes não é divulgado). Este ano, a entrada de um grupo americano na sociedade deve capitalizar a empreitada. STIVALETTI, Thiago; LEITÃo, Gustavo. Novos caminhos do VoD - Explosão do video sob demanda no país amplia modelos de negócios e atrai competidores para as novas plataformas. Movimento também faz produtores repensarem suas estratégias de lançamento. Revista Filme B +, mar. 2016, p.18.

${ }^{9}$ STIVALETTI, Thiago; LEITÃO, Gustavo. Novos caminhos do VoD - Explosão do video sob demanda no país amplia modelos de negócios e atrai competidores para as novas plataformas. Movimento também faz produtores repensarem suas estratégias de lançamento. Revista Filme B +, mar. 2016, p.18.

${ }_{10}$ Adiante, os contratos multinível de availability de obras da Netflix serão analisados à luz da Lei $n^{\circ}$ 8.078/90 (Código de Defesa do Consumidor); da Lei $n^{\circ}$ 9.610/98 (Lei de Direitos Autorais); Lei $n^{\circ}$ 12.965/14 (Lei do Marco Civil da Internet); e da Lei $n^{\circ}$ 13.105/15 (Código de Processo Civil brasileiro, visando identificar os possíveis desdobramentos jurídicos decorrentes de tais contratos multiníveis firmados pela Netflix para o exercício de sua atividade econômica, mais especificamente os desdobramentos jurídicos relacionados à fixação de jurisdição internacional brasileira nas demandas decorrentes de invasões de conteúdos audiovisuais em relação a contratos de sindycation, e aos eventuais direitos autorais decorrentes da execução pública de obras audiovisuais.
} 
ISSN 1981-3694

(DOI): $10.5902 / 1981369431802$

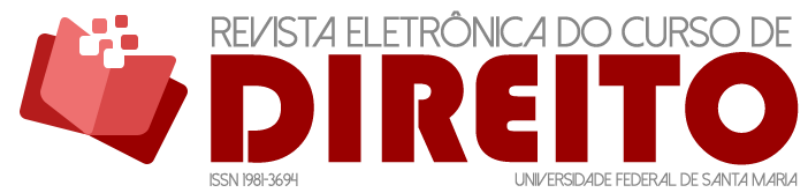

AVAILABILITY DE OBRAS NO NETFLIX E DIREITOS AUTORAIS: COMPLEXIDADES DOS CONTRATOS MULTINIVEL PRODUÇÃO, TRANSMISSÃO E SINDYCATION

EWERTON RICARDO MESSIAS JONATHAN BARROS VITA

à transmissão, à distribuição nacional e ao sindycation ${ }^{11}$, envolvendo direitos e obrigações decorrentes da produção, da transmissão, da distribuição nacional e do sindycation de conteúdos audiovisuais firmados entre a Netflix e os estúdios de produção em cada país ou região; bem como envolvendo direitos e obrigações decorrentes de contratos de prestação de serviço de transmissão online de conteúdos audiovisuais - VoD por meio de streaming da espécie webcasting interativo - firmados entre a Netflix e seus assinantes

\section{PRODUÇÃO DE OBRAS NO NETFLIX}

A Netflix tem cada vez mais apostado em produções originais, para tanto, utiliza sua plataforma online para, por meio de sugestões a seus assinantes, mensurar a quantidade de acessos e a quantidade de assinantes que assistiu do início ao fim um filme, uma série, um documentário ou um show, traçando, assim, a tendência de preferências de seus assinantes em cada região ou país.

A metodologia consiste em, por meio de algoritmos, desenvolvidos para agir da forma mais inteligente, interpretar os movimentos dos assinantes no interior da plataforma online, sugerindo aos assinantes conteúdos audiovisuais a partir da análise de outros filmes já assistidos por eles. Tudo é feito de forma automática pela plataforma online a partir das interações dos assinantes com ela.

Desta forma, a Netflix consegue identificar as preferências de seus assinantes e, assim, investir de forma direcionada e com maior segurança de lucratividade na produção própria de conteúdos audiovisuais, pois consegue retirar da relação contratual os estúdios de produção, de quem teriam que comprar as licenças para distribuição, por meio de contratos de distribuição nacional e/ou de sindycation, nos casos de produções independentes.

Para otimizar a orientação de seus investimentos em produções originais, a Netflix também realiza a contratação de taggers, que são funcionários responsáveis por assistir filmes, séries, documentários, shows, enfim, os conteúdos audiovisuais que vão entrar no catálogo da Netflix e, a partir daí, classifica-los usando tags - palavras-chave.

11 O termo sindycation não possui uma tradução literal para a língua portuguesa, no entanto, uma tradução aproximada seria "contrato de distribuição internacional" ou "contrato de transmissão internacional", no presente trabalho o termo será utilizado com significação de contrato de transmissão internacional, por ser o termo juridicamente adequado ao contido na Lei $\mathrm{n}^{\circ}$ 9.610/1998 - Lei de Direitos Autorais. 
O tagger precisa ser "[...] alguém realmente analítico a ponto de desconstruir filmes e programas, de forma bem subjetiva, com as diferenças de um título para o outro"12.

Todd Yellin, vice-presidente de inovação do Netflix, afirma que o trabalho do tagger é muito específico, pois, ele deve responder questões específicas sobre os conteúdos audiovisuais, tais como - "Ele é escuro? Alegre? Complicado? Simples? Se passa em Nova lorque, em São Paulo, em Estocolmo? A câmera é tremida ou não? Quanto tem de violência? E de sangue? E de nudez?"13.

A plataforma online da Netflix, por meio do algoritmo desenvolvido, cruza as tags com as informações obtidas através das interações dos assinantes com a plataforma, verificando hábitos de audiência e aparelhos mais utilizados para o consumo audiovisual, de forma a orientar o tipo de investimento em produção a ser realizado pela Netflix, para ofertar a seus assinantes conteúdos audiovisuais individualizados, visando a uma maior aceitação, estratégia que se revela como um diferencial no mercado audiovisual.

Enquanto a televisão ou o cinema produzem conteúdos audiovisuais para serem lançados e exibidos para todas as pessoas, independentemente de seu perfil, classe ou sexo, a Netflix produz conteúdos audiovisuais personalizados para cada assinante, por meio de uma plataforma online que permite o acesso individualizado por perfil, permitindo uma experiência diferenciada a seus assinantes, através do VoD por meio de streaming de dados.

No entanto, importante esclarecer que os conteúdos audiovisuais disponibilizados pela Netflix são disponibilizados à massa de assinantes, ou seja, qualquer assinante pode acessar os conteúdos audiovisuais disponibilizados para sua região ou país.

0 produto é de massa e ao mesmo tempo personalizado, pois, o que é disponibilizado à massa é direcionado pela plataforma online, de forma personalizada, aos assinantes, de acordo com suas interações com a plataforma.

Portanto, a Netflix orienta seus investimentos por meio da análise dos dados obtidos pelo algoritmo da plataforma online.

O seu extenso acervo de conteúdos audiovisuais não foi construído por meio de uma simples análise de custo/benefício dos valores das licenças adquiridas dos estúdios, mas também

12 YELLIN, Todd apud ARAÚJO, Bruno. Netflix quer brasileiro para dar pegada local a cardápio de filmes e séries. Entrevista de Todd Yellin ao G1 São Paulo. Disponível em: <http://g1.globo.com/tecnologia/noticia/2015/04/netflix-quer-brasileiro-para-dar-pegada-localcardapio-de-filmes-e-series.html>. Acesso em: 14 mar. 2018.

13 YELLIN, Todd apud ARAÚJO, Bruno. Netflix quer brasileiro para dar pegada local a cardápio de filmes e séries. Entrevista de Todd Yellin ao G1 São Paulo. Disponível em: <http://g1.globo.com/tecnologia/noticia/2015/04/netflix-quer-brasileiro-para-dar-pegada-localcardapio-de-filmes-e-series.html>. Acesso em: 14 mar. 2018. 
ISSN 1981-3694

(DOI): $10.5902 / 1981369431802$

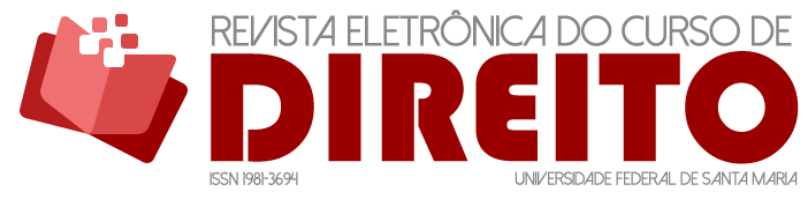

AVAILABILITY DE OBRAS NO NETFLIX E DIREITOS AUTORAIS: COMPLEXIDADES DOS CONTRATOS MULTINIVEL PRODUÇÃO, TRANSMISSÃO E SINDYCATION

EWERTON RICARDO MESSIAS JONATHAN BARROS VITA

por meio do monitoramento dos dados acerca dos conteúdos audiovisuais e de seus próprios assinantes, indicando, no mais das vezes, para a viabilidade de produções originais em detrimento da compra de licenças de produções independentes, visando evitar ou ao menos minimizar problemas relacionados à temporalidade e a geografia da distribuição, nacional e internacional, bem como problemas relacionados a direitos autorais, os quais serão abordados em itens adiante.

\section{TRANSMISSÃO DE OBRAS DO NETFLIX}

A Netflix chegou ao Brasil em setembro de 2011 e seu serviço possui três pacotes de transmissão de conteúdos audiovisuais para os novos assinantes, quais sejam o pacote básico, pelo valor de $\mathrm{R} \$ 19,90$; o pacote padrão, pelo valor de $\mathrm{R} \$ 22,90$; e o pacote premium, pelo valor de $R \$ 29,90^{14}$. Para os novos assinantes o primeiro mês é gratuito para qualquer pacote.

0 acesso ao conteúdo do acervo audiovisual da Netflix é limitado de acordo com o pacote assinado. No entanto, a limitação reside no acesso aos filmes em alta definição (HD) e Ultra HD (4K) e na quantidade de telas que podem assistir os conteúdos audiovisuais simultaneamente ${ }^{15}$.

O pacote básico não disponibiliza aos assinantes acesso aos conteúdos em alta definição (HD) e em Ultra HD (4K), sendo o primeiro disponibilizado aos assinantes dos pacotes padrão e premium, e o segundo disponibilizado apenas aos assinantes do pacote premium ${ }^{16}$.

Em relação à quantidade de telas que podem assistir aos conteúdos audiovisuais simultaneamente, a distinção é que os assinantes do pacote básico somente podem assistir uma tela por vez, enquanto os assinantes do pacote padrão podem assistir até duas telas simultaneamente e os assinantes do pacote premium podem assistir até quatro telas simultaneamente.

As limitações por pacote de assinatura apenas se restringem à qualidade dos conteúdos audiovisuais e à quantidade de reproduções simultâneas. Desta forma, o conteúdo audiovisual disponibilizado e a possibilidade de assistir em qualquer aparelho compatível com o serviço ofertado pela Netflix são os mesmos para qualquer um dos pacotes contratados.

\footnotetext{
${ }^{14}$ Valores referentes ao ano de 2017, conforme divulgado pela Netflix em seu site (NETFLIX, 2017).

${ }^{15}$ NETFLIX Brasil. Planos de assinatura. Disponível em: <https://help.netflix.com/pt/node/412>. Acesso em: 14 mar. 2018.

${ }^{16}$ NETFLIX Brasil. Planos de assinatura. Disponível em: <https://help.netflix.com/pt/node/412>. Acesso em: 14 mar. 2018.
} 
ISSN 1981-3694

(DOI): $10.5902 / 1981369431802$

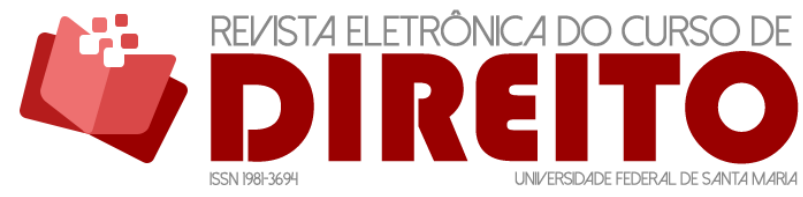

AVAILABILITY DE OBRAS NO NETFLIX E DIREITOS AUTORAIS: COMPLEXIDADES DOS CONTRATOS MULTINIVEL PRODUÇÃO, TRANSMISSÃO E SINDYCATION

EWERTON RICARDO MESSIAS JONATHAN BARROS VITA

A cobrança pela assinatura é realizada uma vez por mês, desta forma os assinantes aderem a um contrato de adesão online, pagando o valor para o uso do pacote escolhido pelo período de um mês, renovando-se, o referido contrato, automaticamente a cada mês, até que o assinante solicite o seu cancelamento, também online.

\section{CONTRATOS DE SINDYCATION NO NETFLIX}

O acervo audiovisual disponibilizado pela Netflix varia de região para região ou de país para país, conforme os contratos de transmissão internacional - sindycation - firmados com os estúdios de produção.

Neste sentido, Reed Hastings afirma que na Europa a Netflix precisa comprar licenças individuais de conteúdo para cada filme ou programa de TV em cada país, como França, Alemanha ou Espanha, já na América Latina a Netflix somente precisa comprar duas licenças, sendo uma para todos os países de língua espanhola e outra para o Brasil ${ }^{17}$.

Conteúdos disponibilizados muitas vezes nos Estados Unidos, Canadá e Reino Unido, não são disponibilizados, no mesmo período, para a América Latina e para outras regiões do planeta, em virtude de questões contratuais.

No caso dos conteúdos não produzidos pela própria Netflix, os estúdios fecham contratos com ela por períodos determinados para cada região ou país ${ }^{18}$. Portanto, caso o estúdio não renove o contrato com a Netflix para determinada região ou país, após o término do período contratado, o conteúdo daquele estúdio deverá ser imediatamente bloqueado para os assinantes da Netflix naquela região ou país.

No entanto, caso um assinante residente no Brasil viaje, por exemplo, para os Estados Unidos, poderá, ele, durante todo o tempo de sua permanência, acessar o conteúdo audiovisual online disponibilizado pela Netflix para os assinantes daquele país.

A Netflix vem enfrentando forte pressão da Australian Home Entertainment Distributors Association - AHEDA -, entidade australiana que representa Warner, Sony e Universal, em virtude

\footnotetext{
17 Hastings, Reed apud GALLAS, Daniel. Como a Netflix driblou a pirataria e fez do Brasil seu 'foguete'. Matéria publicada pela BBC Brasil. Disponível <http://www.bbc.com/portuguese/noticias/2015/11/151123_netflix_pirataria_brasil_dg_fn>. Acesso em: 14 mar. 2018.

18 HASTINGS, Reed. 'Brasileiros ainda não entenderam o Netflix', diz presidente da empresa. Matéria publicada pelo site G1. Disponível em: <http://g1.globo.com/tecnologia/noticia/2012/08/brasileirosainda-nao-entenderam-o-netflix-diz-presidente-da-empresa.html>. Acesso em: 14 mar. 2018.
} 

COMPLEXIDADES DOS CONTRATOS MULTINIVEL PRODUÇÃO, TRANSMISSÃO E SINDYCATION

de frequentes acessos por usuários de uma região ou país aos conteúdos audiovisuais de outras regiões ou países, os quais não estão disponibilizados a tais usuários ${ }^{19}$.

Para acessar os conteúdos não disponibilizados para sua região ou país, tais usuários utilizam programas de desbloqueio, fato que vem fomentando discussões sobre a jurisdição internacional e repercutindo no comércio internacional de produtos e serviços audiovisuais.

\section{JURISIDIÇÃO INTERNACIONAL FRENTE AS DEMANDAS DECORRENTES DOS CONTRATOS DE SINDYCATION DO NETFLIX}

$\mathrm{Na}$ pós-modernidade, com a modernização dos meios de comunicação, proporcionada pela internet, as demandas litigiosas de natureza internacional cresceram exponencialmente. Como exemplo, podem-se citar as demandas litigiosas derivadas dos contratos de sindycation de conteúdos audiovisuais firmados entre a Netflix e os estúdios de produção.

Neste contexto, a definição da jurisdição internacional dos Estados-Nações, de um modo geral, é tema que suscita inúmeras dúvidas e controvérsias, entre elas, a dúvida atinente aos limites da jurisdição internacional brasileira em relação aos casos de invasão de conteúdos audiovisuais por assinantes do Netflix, tanto no que tange às invasões realizadas por assinantes brasileiros a conteúdos audiovisuais exibidos em outras regiões ou países, não contemplados em seus pacotes de assinatura, quanto no que tange às invasões realizadas por assinantes estrangeiros a conteúdos audiovisuais exibidos apenas no Brasil e, portanto, não contemplados em seus pacotes de assinatura.

O exercício da jurisdição é o meio pelo qual o Estado-Nação atua para corrigir a não observância espontânea de seus mandamentos normativos. Portanto, com o exercício da jurisdição o Estado-Nação busca restaurar a estabilidade e o bem-estar social, por meio da eliminação de conflitos, mediante a aplicação de soluções normativas contidas no sistema jurídico ${ }^{20}$.

\footnotetext{
${ }^{19}$ MILLS. Chris. Netflix está sob pressão para impedir acesso ao catálogo americano através de VPN. Disponível em: <http://gizmodo.uol.com.br/netflix-impedir-vpn/>. Acesso em: 14 mar. 2018.

20 Segundo Jonathan Barros Vita, "o sistema jurídico é formado pela interpretação normativa sob a forma unificadora de norma, ou seja, é um rearranjo de ciência do direito, em que se eliminam as contradições e se estrutura sintaticamente o direito, é linguagem descritiva que possui como fundo uma linguagem prescritiva". VITA, Jonathan Barros. Valoração aduaneira e preços de transferência: pontos de conexão e distinções sistêmico-aplicativas. 2010. 927f. Tese de Doutorado - Pontifícia Universidade Católica. $\quad$ São Paulo, p.41. Disponível em:
} 

COMPLEXIDADES DOS CONTRATOS MULTINIVEL PRODUÇÃO, TRANSMISSÃO E SINDYCATION

Nesta linha de raciocínio, jurisdição internacional é o exercício do poder jurisdicional de um Estado-Nação em relação a uma demanda litigiosa envolvendo mais de um Estado-Nação.

A jurisdição internacional está sujeita às normas específicas sobre tal assunto, ou seja, está sujeita às regras e princípios que lhe impõem um grau de limitação suficiente a garantir a obediência à soberania dos Estados-Nações, afastando a possibilidade de sua universalização.

Considerando a soberania e o princípio Lex fori, a fixação de jurisdição internacional dá-se através de normas próprias internas de cada Estado-Nação.

Assim, os critérios de delimitação da jurisdição internacional de suas autoridades jurisdicionais são fixados por cada Estado-Nação, de acordo com o seu juízo próprio de adequação.

De acordo com as regras de direito internacional, um Estado-Nação não pode tratar sobre a delimitação de competência internacional dos demais Estados-Nações.

No Brasil as normas de competência internacional encontram-se basicamente nos artigos 21 a 25 do Novo Código de Processo Civil Brasileiro - NCPC, Lei $n^{\circ} 13.105 / 2015^{21}$; na Lei de Introdução às Normas de Direito Brasileiro - LINDB -, em algumas unidades enunciativas esparsas $^{22}$ no ordenamento jurídico ${ }^{23}$ brasileiro, e nos tratados, convenções ou acordos internacionais que tratam sobre jurisdição internacional e que se encontram em vigor no Brasil.

No caso específico das demandas litigiosas derivadas dos contratos de sindycation de conteúdos audiovisuais firmados entre a Netflix e os estúdios de produção, interessa a

<https://sapientia.pucsp.br/bitstream/handle/5458/1/Jonathan\%20Barros\%20Vita.pdf>. Acesso em: 06 abr 2018.

21 BRASIL. Lei $\mathrm{n}^{\circ}$ 13.105, de 16 de março de 2015. Código de Processo Civil. Disponível em: <http://www.planalto.gov.br/ccivil_03/_ato2015-2018/2015/lei//13105.htm>. Acesso em: 15 jun. 2018.

22 Paulo de Barros Carvalho explica que "seja como for, o processo de interpretação não pode abrir mão das unidades enunciativas esparsas do sistema positivo, elaborando suas significações frásicas para, somente depois, organizar as entidades normativas (sentido estrito). Principalmente porque o sentido completo das mensagens do direito depende da integração de enunciados que indiquem as pessoas (físicas e jurídicas), suas capacidades ou competências, as ações que podem ou devem praticar, tudo em determinadas condições de espaço e de tempo. A teoria comunicacional, aliás, trata admiravelmente bem desse tema, organizando os enunciados do direito positivo (ordenamento) de tal modo que facilite as providências subsequentes da montagem comunicativa". CARVALHO, Paulo de Barros. Direito Tributário, Linguagem e Método. $3^{\text {a }}$ ed. São Paulo: Noeses, 2009, p.131.

23 Jonathan Barros Vita explica que "o ordenamento jurídico pode ser considerado como o dado bruto, ou seja, é o texto jurídico da forma em que foi legislado, que é sistema pelo fato de possuir: homogeneidade finalística, que seja, a regulação de condutas humanas e o tipo de linguagem que, também, é homogêneo, linguagem prescritiva". VITA, Jonathan Barros. Valoração aduaneira e preços de transferência: pontos de conexão e distinções sistêmico-aplicativas. 2010. 927f. Tese de Doutorado Pontifícia Universidade Católica. São Paulo, p.41. Disponível em: <https://sapientia.pucsp.br/bitstream/handle/5458/1/Jonathan\%20Barros\%20Vita.pdf>. Acesso em: 06 abr 2017. 

COMPLEXIDADES DOS CONTRATOS MULTINIVEL PRODUÇÃO, TRANSMISSÃO E SINDYCATION

interpretação ${ }^{24}$ sistemática, no âmbito do Direito brasileiro, do contido no artigo 22, inciso II, do NCPC, o qual dispõe que compete à autoridade judiciária brasileira julgar as ações decorrentes de relações de consumo, desde que o consumidor tenha domicílio ou residência no Brasil ${ }^{25}$.

A relação estabelecida entre a Netflix e os assinantes de quaisquer de seus pacotes de serviços, trata-se de relação de consumo, visto que o próprio Termo de uso da Netflix, em seu item 4.2. ${ }^{26}$, prevê o assinante como destinatário final da prestação de serviço de acesso online aos conteúdos audiovisuais, enquadrando-se perfeitamente ao previsto no artigo $2^{\circ}$, da Lei $n^{\circ}$ 8.078/1990, o qual prevê que "consumidor é toda pessoa física ou jurídica que adquire ou utiliza produto ou serviço como destinatário final”27.

Desta forma, compete à autoridade judiciária brasileira julgar ações judiciais decorrentes de demandas litigiosas relacionadas às invasões de conteúdos audiovisuais do Netflix por assinantes que tenham domicílio ou residência no Brasil.

Importante salientar que tais demandas litigiosas originam-se de contratos multinível, envolvendo direitos e obrigações decorrentes de contratos de sindycation de conteúdos audiovisuais firmados entre a Netflix e os estúdios de produção; e direitos e obrigações decorrentes de contratos de prestação de serviço de transmissão online de conteúdos audiovisuais - VoD por meio de streaming da espécie webcasting interativo - firmados entre a Netflix e seus assinantes que tenham domicílio ou residência no Brasil.

\footnotetext{
${ }^{24}$ Entendida como o processo por meio do qual o intérprete do Direito - sujeito do conhecimento -, com base na sua ideologia e no seu universo de linguagem, constrói o sentido oculto no texto do enunciado prescritivo do direito positivo. Assim, o intérprete do Direito parte da leitura dos enunciados prescritivos do direito positivo para a construção das significações, dos sentido ocultos em tais enunciados. Trata-se, portanto, de uma atividade de construção e não meramente de descoberta ou extração do sentido dos enunciados prescritivos. CARVALHO, Paulo de Barros. Breves considerações sobre a função descritiva da Ciência do Direito Tributário. Disponível em http://www.conjur.com.br/2013-out-01/paulo-barrosbreves-consideracoes-funcao-descritiva-ciencia-direito-tributario. Acesso em 15 jun. 2018.

25 BRASIL. Lei $\mathrm{n}^{\circ}$ 13.105, de 16 de março de 2015. Código de Processo Civil. Disponível em: <http://www.planalto.gov.br/ccivil_03/_ato2015-2018/2015/lei//13105.htm>. Acesso em: 15 jun. 2018.

${ }^{26}$ Termo de uso da Netflix [...] 4. Serviço Netflix [...] 4.2. O serviço Netflix e todo o conteúdo visualizado por intermédio do serviço Netflix destina-se exclusivamente para uso pessoal e não comercial. Durante sua assinatura Netflix, a Netflix concede a você uma licença limitada, não exclusiva e não transferível para acessar o serviço Netflix e assistir ao conteúdo da Netflix. Com exceção à licença limitada descrita acima, nenhum outro direito, titularidade ou participação the é concedido. Você concorda em não utilizar o serviço para exibições públicas. NETFLIX Brasil. Termo de uso. Disponível em: <https://help.netflix.com/legal/termsofuse>. Acesso em: 14 jun. 2018.

27 BRASIL. Lei $n^{\circ} \mathbf{8 . 0 7 8}$, de 11 de setembro de 1990. Dispõe sobre a proteção do consumidor e dá outras providências. Disponível em: <http://www.planalto.gov.br/ccivil_03/leis/L8078.htm>. Acesso em: 14 jun. 2018.
} 

COMPLEXIDADES DOS CONTRATOS MULTINIVEL PRODUÇÃO, TRANSMISSÃO E SINDYCATION

EWERTON RICARDO MESSIAS JONATHAN BARROS VITA

No Brasil não há lei específica que regulamente a assinatura e os serviços de acesso online aos conteúdos audiovisuais, nem o Marco Civil da Internet, na forma da Lei $\mathrm{n}^{\circ}$ 12.965/2014 ${ }^{28}$, regulamenta tal assunto.

No Termo de uso da Netflix ${ }^{29}$ há previsão das penalidades de encerramento da conta ou restriçãa da utilização dos serviços, caso o usuário degrade ou adultere quaisquer das proteções de conteúdo do serviço Netflix, use qualquer robô, spider, scraper ou outros meios automatizados para acessar o serviço Netflix.

Diante de tal panorama, como no Brasil não há lei específica que regulamente a assinatura e os serviços de acesso online a conteúdos audiovisuais, tal cláusula poderia ser considerada abusiva e, portanto, ilegal?

Sendo uma relação de consumo, a relação estabelecida entre a Netflix e os assinantes de seus pacotes de serviços, de acordo com o artigo $4^{\circ}$, inciso III, da Lei $\mathrm{n}^{\circ} 8.078 / 1990^{30}$, a cláusula contida no item 4.2. do seu Termo de uso não se revela abusiva ou ilegal, pois, baseada no princípio da boa-fé objetiva ${ }^{31}$, lastreada na confiança e na lealdade entre as partes contratantes, de forma a garantir o equilíbrio contratual.

${ }^{28}$ BRASIL. Lei $\mathrm{n}^{\circ} \mathbf{1 2 . 9 6 5}$, de 23 de abril de 2014. Estabelece princípios, garantias, direitos e deveres para o uso da Internet no Brasil. Disponível em: <http://www.planalto.gov.br/ccivil_03/_ato20112014/2014/lei/l12965.htm>. Acesso em: 15 jun. 2018.

29 Termo de uso da Netflix [...] 4. Serviço Netflix [...] 4.6. Você concorda em usar o serviço Netflix, incluindo todos os recursos e funcionalidades do mesmo, segundo todas as leis, regulamentos e códigos aplicáveis, assim como outras restrições de uso do serviço ou conteúdo previstas nas mesmas. Você concorda em não arquivar, reproduzir, distribuir, modificar, exibir, realizar, publicar, licenciar ou criar trabalhos derivados, colocar à venda ou utilizar (exceto nas formas expressamente autorizadas por estes Termos de uso) o conteúdo e as informações contidas ou obtidas do serviço Netflix ou por intermédio deste. Você também concorda em não: evadir, remover, alterar, desativar, degradar ou adulterar quaisquer das proteções de conteúdo do serviço Netflix, usar qualquer robô, spider, scraper ou outros meios automatizados para acessar o serviço Netflix, descompilar, executar engenharia reversa ou desmembrar qualquer software ou outros produtos ou processos acessíveis pelo serviço Netflix, inserir qualquer código ou produto, manipular o conteúdo do serviço Netflix de qualquer forma ou usar métodos de data mining, coleta de dados ou extração de dados. Além disso, você concorda em não fazer upload, publicar, enviar por e-mail, comunicar ou transmitir de qualquer forma qualquer material designado para interromper, destruir ou limitar a funcionalidade de qualquer software, hardware ou equipamento de telecomunicações associado ao serviço Netflix, incluindo vírus de software, código, arquivos ou programas. A Netflix poderá cancelar ou restringir seu uso do serviço se você violar estes Termos de uso ou se envolver no uso ilegal ou fraudulento do serviço. NETFLIX Brasil. Termo de uso. Disponível em: <https://help.netflix.com/legal/termsofuse>. Acesso em: 14 jun. 2018.

${ }^{30}$ BRASIL. Lei $n^{\circ} \mathbf{8 . 0 7 8}$, de 11 de setembro de 1990. Dispõe sobre a proteção do consumidor e dá outras providências. Disponível em: <http://www.planalto.gov.br/ccivil_03/leis/L8078.htm>. Acesso em: 14 jun. 2018.

31 Para Sérgio Cavalieri Filho a boa-fé objetiva “[...] representa o padrão ético de confiança e lealdade indispensável para a convivência social. As partes devem agir com lealdade e confiança recíprocas. Essa expectativa de um comportamento adequado por parte do outro é um componente indispensável na vida de relação". CAVALIERI FILHO, Sergio. Programa de direito do consumidor. São Paulo: Atlas, 2009, p.143. 
Como dito, no mais das vezes a Netflix firma contrato de Sindycation de conteúdos audiovisuais com estúdios de produção, os quais delimitam o período, a região ou os países em que os conteúdos podem ser exibidos.

Portanto, a Netflix possui o dever de manter o equilíbrio contratual em relação a tais estúdios, por tal motivo deve agir para evitar a invasão de conteúdos audiovisuais por assinantes localizados em regiões ou países onde eles não estão autorizados a serem exibidos.

É neste aspecto que se afirma que a cláusula contida no item 4.2. do Termo de uso da Netflix não se revela abusiva ou ilegal, pois, baseada na boa-fé objetiva, a qual deve informar todos os contratos de consumo em solo brasileiro, no caso, um contrato multinível que se forma da relação Netflix - estúdios - Netflix - assinantes.

Há um claro tensionamento entre o desenvolvimento tecnológico propiciado pela internet e a forma como funciona a transmissão de conteúdo audiovisual, diante dos contratos multinível, que se formam da relação Netflix - estúdios • Netflix • assinantes, e das normas que regem tais contratos em cada país.

Enquanto há evolução no acesso das pessoas à escolha de conteúdos audiovisuais em menor tempo, de onde quiserem e quando quiserem; a transmissão desses conteúdos sofre com a estagnação das normas que regem os contratos que a disciplinam, de forma a limitar temporal e geograficamente a transmissão dos conteúdos, fato que torna a globalização da prestação de serviços pela Netflix, ao menos por ora, um objetivo não alcançado, mas ainda a ser almejado.

Porém, a dificuldade em disponibilizar os conteúdos de forma global também está ligada a outro fator, qual seja a discussão de lucros entre os produtores - detentores dos direitos autorais - e a Netflix, assunto que será tratado no próximo item.

\section{DIREITOS AUTORAIS}

A Constituição Federal de 1988 erigiu os direitos autorais ao patamar de direito fundamental, ao prever, no artigo $5^{\circ}$, inciso XXVII, da Constituição Federal, que ao autor é concedido o "direito exclusivo de utilização, publicação ou reprodução de suas obras, 

COMPLEXIDADES DOS CONTRATOS MULTINIVEL PRODUÇÃO, TRANSMISSÃO E SINDYCATION

transmissível aos herdeiros pelo tempo que a lei fixar"32, conferindo-lhe ainda o direito de fiscalização sobre a utilização econômica das obras que criar ou em que participar da criação ${ }^{33}$.

A legislação brasileira acerca dos direitos autorais é adequada à proteção das mais diversas produções do intelecto humano, no entanto, têm surgido diversas discussões acerca de sua [in]suficiência para a resolução de direitos autorais associados às tecnologias digitais da informação e comunicação (TDIC) $)^{34}$.

Conforme já abordado, a Netflix oferece seus serviços através de uma plataforma de vídeo sob demanda - Subscricion vídeo on demand - SVoD - por meio de streaming, da espécie webcasting interativo.

Assim, a Netflix não pode ser considerada como TV, realidade que traz à tona dúvidas acerca da sujeição do seu serviço de transmissão de conteúdos audiovisuais, por meio de streaming da espécie webcasting interativo, ao pagamento de direitos autorais.

No Brasil, é a Lei $n^{\circ}$ 9.610/1998, conhecida como Lei dos Direitos Autorais - LDA ${ }^{35}$, que disciplina os direitos autorais, atribuindo-lhes atributos personalíssimos - ligados à moral do autor - e patrimoniais - ligados à exploração econômica da obra, respectivamente, em seus artigos 24 e 29.

Desta forma, o artigo 29, da $\operatorname{LDA}^{36}$, em rol exemplificativo, prevê as modalidades de utilização da obra, que dependem de autorização prévia e expressa do autor.

O legislador preocupou-se a dar ao autor a mais ampla proteção de sua criação ${ }^{37}$, não importando o meio de transmissão empregado, mas sim a circunstância da transmissão, ao

32 BRASIL. Constituição da República Federativa do Brasil de 1988. Disponível em: <http://www.planalto.gov.br/ccivil_03/constituicao/constituicaocompilado.htm>. Acesso em: 03. Set. 2018.

${ }^{33}$ PIRES, E; REIS, J.R. A utilização das Obras intelectuais Autorais Frente às novas Tecnologias: Função Social ou Pirataria?. Revista do Direito Unisc, Santa Cruz do Sul, v. 34, p. 27-40, 2010.

${ }^{34}$ DIAS, Guilherme Ataíde; SOUSA, Rosilene Paiva Marinho de; PAIVA, Maria josé Rodrigues. Direito autoral e preservação digital: considerações pertinentes a periódicos científicos eletrônicos mantidos no sistema LOCKSS. Ciência da Informação, Brasília, v. 41 n. 1, p.92-102, jan./abr., 2012.

35 BRASIL. Lei $\mathrm{n}^{\circ} \mathbf{9 . 6 1 0}$, de 19 de fevereiro de 1998. Altera, atualiza e consolida a legislação sobre direitos autorais dá outras providências. Disponível em: <http://www.planalto.gov.br/ccivil_03/leis/L9610.htm>. Acesso em: 03 set. 2018.

${ }^{36}$ BRASIL. Lei $\mathrm{n}^{\circ} \mathbf{9 . 6 1 0}$, de 19 de fevereiro de 1998. Altera, atualiza e consolida a legislação sobre direitos autorais dá outras providências. Disponível em: <http://www.planalto.gov.br/ccivil_03/leis/L9610.htm>. Acesso em: 03 set. 2018.

${ }^{37}$ Ao tratar da amplitude de alcance objetivado pelo legislador, o Ministro Ricardo Villas Bôas Cueva afirma que "[...] é possível constatar que a lei autoral não traz nominalmente as mídias por meio das quais as obras são utilizadas, contudo, delineia as diretrizes básicas e os conceitos fundamentais capazes de abarcar diversas modalidades de utilização de produções intelectuais no atual ambiente virtual, bem como lança-se para o futuro quando se refere a "quaisquer outras modalidades que venham a ser inventadas". Ou seja, a preocupação do legislador foi a de fornecer ao autor mecanismos de proteção à 

COMPLEXIDADES DOS CONTRATOS MULTINIVEL PRODUÇÃO, TRANSMISSÃO E SINDYCATION

menos é o que se infere da interpretação conjunta do contido no artigo 29, caput; VII; VIII, “i”; e X, da $\operatorname{LDA}^{38}$.

Conforme já abordado, a Netflix transmite conteúdos audiovisuais a seus assinantes através de SVoD, por meio de streaming na modalidade webcasting interativo, ou seja, a Netflix coloca à disposição obras audiovisuais por meio da internet - streaming, permitindo a seus assinantes que selecionem os conteúdos a serem assistidos, bem como o momento e o local onde tais conteúdos serão assistidos, por meio da disponibilização no ambiente Web - webcasting interativo, mediante pagamento mensal de um dos pacotes oferecidos, amoldando-se, perfeitamente, ao contido no artigo 29, caput e inciso VII, VII; VIII, “i”; e X, da LDA ${ }^{39}$, configurando-se, portanto, em modalidade de exploração econômica de obra audiovisual, a qual necessita de prévia e expressa autorização dos titulares de direito para sua realização.

Identificada a necessidade prévia e expressa do titular do direito para transmissão de conteúdo audiovisual através de SVoD, por meio de streaming da espécie webcasting interativo, cumpre verificar se tal transmissão enquadra-se no conceito de execução pública, o que autorizaria as associações representativas dos autores e dos titulares de direitos conexos a cobrar os direitos autorais, conforme se pode extrair da interpretação do contido no artigo 97, caput, combinado com o artigo 98, caput e $\$ 1^{\circ}$, da LDA ${ }^{40}$.

A LDA trata da execução pública em seu Capítulo II, Título IV, artigo 68, §§ $2^{\circ}$ e $3^{\circ}$, da $\operatorname{LDA}^{41}$, da interpretação de tais dispositivos legais, pode-se extrair dois entendimentos. 0 primeiro é que as obras audiovisuais revelam-se como espécie do gênero obras artísticas; e o segundo é que a utilização de obras audiovisuais, por quaisquer processos, inclusive a

sua criação, apresentando vasto campo de utilização em que a obra intelectual está coberta, tanto no presente como no futuro, perdendo relevância, assim, o meio em que foi expressa. De fato, o que importa é a circunstância de a obra ter sido difundida”. BRASIL. Superior Tribunal de Justiça. Recurso Especial $\mathrm{n}^{\circ}$ 1.559.264 - RJ. Relator Ministro Ricardo Villas Bôas Cueva. Julgado em 08/02/2017. Disponível em: <https://ww2.stj.jus.br/processo/revista/documento/mediado/?componente=ITA\&sequencial=1518691\&n um_registro=201302654647\&data=20170215\&formato=PDF>. Acesso em: 15 jun. 2018.

${ }_{38}$ BRASIL. Lei $n^{\circ}$ 9.610, de 19 de fevereiro de 1998. Altera, atualiza e consolida a legislação sobre direitos autorais e dá outras providências. Disponível em: <http://www.planalto.gov.br/ccivil_03/leis/L9610.htm>. Acesso em: 03 set. 2018.

${ }^{39}$ BRASIL. Lei $n^{\circ}$ 9.610, de 19 de fevereiro de 1998. Altera, atualiza e consolida a legislação sobre direitos autorais e dá outras providências. Disponível em: <http://www.planalto.gov.br/ccivil_03/leis/L9610.htm>. Acesso em: 03 set. 2018.

${ }^{40}$ BRASIL. Lei $n^{\circ}$ 9.610, de 19 de fevereiro de 1998. Altera, atualiza e consolida a legislação sobre direitos autorais e dá outras providências. Disponível em: <http://www.planalto.gov.br/ccivil_03/leis/L9610.htm>. Acesso em: 03 set. 2018.

${ }^{41}$ BRASIL. Lei $\mathrm{n}^{\circ} \mathbf{9 . 6 1 0}$, de 19 de fevereiro de 1998. Altera, atualiza e consolida a legislação sobre direitos autorais e dá outras providências. Disponível em: <http://www.planalto.gov.br/ccivil_03/leis/L9610.htm>. Acesso em: 03 set. 2018. 

COMPLEXIDADES DOS CONTRATOS MULTINIVEL PRODUÇÃO, TRANSMISSÃO E SINDYCATION

transmissão por qualquer modalidade, em local de frequência coletiva, revela-se como execução pública.

0 artigo $5^{\circ}$, inciso II, da LDA ${ }^{42}$, considera como transmissão a difusão de som e imagens, por meio de ondas radioelétricas; sinais de satélite; fio, cabo ou outro condutor; meios óticos ou qualquer outro processo eletromagnético.

O inciso VIII, “i”, do mesmo artigo, considera como obra audiovisual a que resulta da fixação de imagens com ou sem som, que tenha a finalidade de criar, por meio de sua reprodução, a impressão de movimento, independentemente dos processos de sua captação, do suporte usado inicial ou posteriormente para fixá-lo, bem como dos meios utilizados para sua veiculação ${ }^{43}$.

Ao tratar sobre a complexidade da criação humana e o caminho a ser percorrido para a criação de uma obra audiovisual, Marcos Alberto Sant'anna Bitelli afirma que:

0 produto da criação humana parte do simples para o complexo. A tutela desses direitos vem do indivíduo, da pessoa humana para o grupo e do grupo para a atividade industrial. A obra audiovisual também faz esse caminho, contudo, a dificuldade é o fato de que na sua junção (fusão de elementos integrantes) não se configura numa obra coletiva, mas sim numa obra complexa, em que as contribuições individuais se dissolvem e combinam entre si como numa reação química quase irreversível. Aliás, como substância, a obra audiovisual por ser obra autônoma, pelo princípio da inalterabilidade e intangibilidade da criação, pode tornar irreversível a combinação quando consideradas cada uma das partículas que a integram como elementos formadores do todo. Um filme não será exibido mutilado, sem uma música que o integrou, um fonograma, uma imagem cênica, um diálogo, sem uma interpretação artística e assim por diante $^{44}$.

A obra audiovisual trata-se de uma obra complexa, realizada em coautoria, ou seja, trata-se de um todo formado por partes integrantes que não podem e não devem ser consideradas isoladamente, pois, caso suprimida uma delas, não haverá o todo complexo. Desta forma:

\footnotetext{
${ }^{42}$ BRASIL. Lei $\mathrm{n}^{\circ}$ 9.610, de 19 de fevereiro de 1998. Altera, atualiza e consolida a legislação sobre direitos autorais e dá outras providências. Disponível em: <http://www.planalto.gov.br/ccivil_03/leis/L9610.htm>. Acesso em: 03 set. 2018.

${ }^{43}$ BRASIL. Lei $\mathrm{n}^{\circ}$ 9.610, de 19 de fevereiro de 1998. Altera, atualiza e consolida a legislação sobre direitos autorais e dá outras providências. Disponível em: <http://www.planalto.gov.br/ccivil_03/leis/L9610.htm>. Acesso em: 03 set. 2018.

44 BITELLI, Marcos Alberto Sant'anna. O direito de autor e as obras audiovisuais. Revista do Centro de Estudos Judiciários, Brasília, n. 21, p. 40-44, abr./jun. 2003, p.41.
} 

COMPLEXIDADES DOS CONTRATOS MULTINIVEL PRODUÇÃO, TRANSMISSÃO E SINDYCATION

[...] os co-autores da obra audiovisual e os demais contribuintes, quando autorizam na forma do art. 29, V, da Lei n. 9.610/98, a inclusão de sua parcela para fusão em produção audiovisual, por força do art. 81 da mesma lei, estão automaticamente autorizando a distribuição comercial, a exibição e a comunicação ao público ${ }^{45}$.

Assim, as obras audiovisuais revelam-se como uma obra complexa, espécie do gênero obras artísticas, sendo sua utilização em local de frequência coletiva, por quaisquer processos, inclusive a transmissão por qualquer modalidade, considerada execução pública.

Portanto, nos termos do artigo 29, inciso V, combinado com o artigo 81, da LDA ${ }^{46}$, revela-se lícita a cobrança dos direitos autorais dos autores e de titulares de direitos conexos, por associação que thes represente, em relação à execução pública da obra audiovisual, considerada como um todo complexo. Assim, seria lícito que associações de autores e coautores de obras audiovisuais, devidamente habilitadas em Órgão da Administração Pública Federal, cobrassem direitos autorais pela execução pública de obras audiovisuais.

Também, com base no artigo 86 , da $\operatorname{LDA}^{47}$, revela-se lícita a cobrança de direitos autorais por qualquer associação de autores ou coautores de obras musicais, literomusicais ou fonográficas, desde que devidamente habilitadas em Órgão da Administração Pública Federal, em virtude de execução pública de conteúdo musical, ainda que incorporado a conteúdo audiovisual.

Da interpretação conjunta dos incisos II e VIII, “i”, do artigo $5^{\circ}$, da LDA ${ }^{48}$, é possível afirmar que o SVoD, por meio de streaming da espécie webcasting interativo, trata-se de tecnologia que possibilita a difusão pela internet, enquadrando-se entre as modalidades, previstas em lei, por meio da qual as obras audiovisuais são transmitidas.

Enquadrado legalmente o SVoD, por meio de streaming da espécie webcasting interativo, como uma modalidade pela qual as obras audiovisuais são transmitidas, resta

\footnotetext{
45 BITELLI, Marcos Alberto Sant'anna. O direito de autor e as obras audiovisuais. Revista do Centro de Estudos Judiciários, Brasília, n. 21, p. 40-44, abr./jun. 2003, p.42.

${ }^{46}$ BRASIL. Lei $\mathrm{n}^{\circ}$ 9.610, de 19 de fevereiro de 1998. Altera, atualiza e consolida a legislação sobre direitos autorais e dá outras providências. Disponível em: <http://www.planalto.gov.br/ccivil_03/leis/L9610.htm>. Acesso em: 03 set. 2018.

${ }^{47}$ BRASIL. Lei $\mathrm{n}^{\circ}$ 9.610, de 19 de fevereiro de 1998. Altera, atualiza e consolida a legislação sobre direitos autorais e dá outras providências. Disponível em: <http://www.planalto.gov.br/ccivil_03/leis/L9610.htm>. Acesso em: 03 set. 2018.

${ }^{48}$ BRASIL. Lei $\mathrm{n}^{\circ}$ 9.610, de 19 de fevereiro de 1998. Altera, atualiza e consolida a legislação sobre direitos autorais e dá outras providências. Disponível em: <http://www.planalto.gov.br/ccivil_03/leis/L9610.htm>. Acesso em: 03 set. 2018.
} 

COMPLEXIDADES DOS CONTRATOS MULTINIVEL PRODUÇÃO, TRANSMISSÃO E SINDYCATION

determinar se o mesmo situa-se no âmbito do direito de comunicação ao público, artigo $5^{\circ}$, inciso V, da LDA, ou no âmbito do direito de distribuição, artigo $5^{\circ}$, inciso IV, da LDA ${ }^{49}$.

Conforme já esclarecido, no SVoD, por meio de streaming da espécie webcasting interativo, o conteúdo audiovisual é colocado à disposição do assinante no ambiente Web, o qual acessa o conteúdo que escolher, quando escolher, do aparelho que escolher, desde que compatível com os serviços Netflix, e de onde estiver, não havendo, assim, a realização de download, mas sim o acesso interativo no próprio ambiente Web.

Desta forma, o serviço ofertado pela Netflix situa-se no âmbito do direito de comunicação ao público, artigo $5^{\circ}$, inciso $\mathrm{V}$, da $\operatorname{LDA}^{50}$, o qual se relaciona ao direito de colocar à disposição do público; e não no âmbito do direito de distribuição, artigo $5^{\circ}$, inciso IV, da LDA ${ }^{51}$, o qual se relaciona ao direito transferência de propriedade ou posse, o que não ocorre no SVoD por streaming da espécie webcasting interativo da Netflix.

No mesmo sentido, prevê a Directiva 2001/29/CE do Parlamento Europeu e do seu Conselho, de 22 de maio de 2001, a qual trata da harmonização de certos aspectos do direito de autor e dos direitos conexos na sociedade da informação:

\section{$[\ldots]$}

Considerando o seguinte:

(23) A presente directiva deverá proceder a uma maior harmonização dos direitos de autor aplicáveis à comunicação de obras ao público. Esses direitos deverão ser entendidos no sentido lato, abrangendo todas as comunicações ao público não presente no local de onde provêm as comunicações. Abrangem ainda qualquer transmissão ou retransmissão de uma obra ao público, por fio ou sem fio, incluindo a radiodifusão, não abrangendo quaisquer outros actos.

(24) 0 direito de colocar à disposição do público materiais contemplados no n.o 2 do artigo 3.o deve entender-se como abrangendo todos os actos de colocação desses materiais à disposição do público não presente no local de onde provém esses actos de colocação à disposição, não abrangendo quaisquer outros actos

[...]

Artigo $3^{\circ}$ Direito de comunicação de obras ao público, incluindo o direito de colocar à sua disposição outro material

1. Os Estados-Membros devem prever a favor dos autores o direito exclusivo de autorizar ou proibir qualquer comunicação ao público das suas obras, por

\footnotetext{
${ }^{49}$ BRASIL. Lei $\mathrm{n}^{\circ}$ 9.610, de 19 de fevereiro de 1998. Altera, atualiza e consolida a legislação sobre direitos autorais e dá outras providências. Disponível em: <http://www.planalto.gov.br/ccivil_03/leis/L9610.htm>. Acesso em: 03 set. 2018.

${ }^{50}$ BRASIL. Lei $n^{\circ}$ 9.610, de 19 de fevereiro de 1998. Altera, atualiza e consolida a legislação sobre direitos autorais e dá outras providências. Disponível em: <http://www.planalto.gov.br/ccivil_03/leis/L9610.htm>. Acesso em: 03 set. 2018.

${ }^{51}$ BRASIL. Lei $\mathrm{n}^{\circ}$ 9.610, de 19 de fevereiro de 1998. Altera, atualiza e consolida a legislação sobre direitos autorais e dá outras providências. Disponível em: <http://www.planalto.gov.br/ccivil_03/leis/L9610.htm>. Acesso em: 03 set. 2018.
} 

COMPLEXIDADES DOS CONTRATOS MULTINIVEL PRODUÇÃO, TRANSMISSÃO E SINDYCATION

EWERTON RICARDO MESSIAS JONATHAN BARROS VITA

fio ou sem fio, incluindo a sua colocação à disposição do público por forma a torná-las acessíveis a qualquer pessoa a partir do local e no momento por ela escolhido ${ }^{52}$ (grifo nosso).

Sendo o SVoD por streaming da espécie webcasting interativo uma modalidade pela qual as obras audiovisuais são transmitidas, no exercício do direito de comunicação ao público, resta determinar se a internet pode ser considerada um local de frequência coletiva, para, enfim, determinar se a transmissão de obras audiovisuais pela plataforma SVoD por streaming da espécie webcasting interativo trata-se de execução pública de obra audiovisual, de forma a autorizar a cobrança de direitos autorais, por associação de autores e coautores de obras audiovisuais, em virtude das transmissões de obras audiovisuais pela Netflix e outras empresas de SVoD por streaming da espécie webcasting interativo.

Tanto o conceito de comunicação ao público, prevista no artigo $5^{\circ}$, inciso $\mathrm{V}$, da LDA, quanto o conceito de execução pública, prevista no artigo $68, \S \S 2^{\circ}$ e $3^{\circ}$, da $\operatorname{LDA}^{53}$, abrangem a utilização de obras audiovisuais colocadas ao alcance público por quaisquer processos, inclusive a transmissão por qualquer modalidade e em qualquer ambiente que alcance número indeterminado e irrestrito de usuários e locais.

A internet trata-se de uma rede mundial de computadores interligados por uma modalidade de transmissão digital, a qual permite acesso, aos conteúdos por ela transmitidos, a um número irrestrito de usuários, distribuídos por todo o planeta.

Portanto, a internet pode ser compreendida como um local de frequência coletiva, por meio do qual houve uma potencialização exponencial da exploração econômica de conteúdos audiovisuais, que outrora eram transmitidos apenas por meio de LPs, Fitas Cassetes, CDs, DVDs, BlueRay etc, os quais eram remetidos aos usuários individualmente e via serviços de postagem física, como, por exemplo, no Brasil, via Empresas de Correios e Telégrafos.

Importante salientar que, tanto para comunicação pública quanto para a execução pública, o que importa é disponibilização do conteúdo audiovisual ao alcance público, por qualquer meio de transmissão, desta forma, ainda que o conteúdo seja acessado individualmente pelo usuário, como ocorre no SVoD por streaming da espécie webcasting interativo, tratar-se-á a internet de local de frequência coletiva, pois, em que pese o acesso ser individualizado, por

52 PARLAMENTO EUROPEU. DIRECTIVA 2001/29/CE, de 22 de Maio de 2001. In: Jornal Oficial das Comunidades Européias, L 167/12, 22.06.2001. Disponível em: <http://eur-lex.europa.eu/legalcontent/PT/TXT/PDF/?uri=CELEX:32001L0029\&from=PT>. Acesso em: 16 mar. 2018.

${ }^{53}$ BRASIL. Lei $\mathrm{n}^{\circ}$ 9.610, de 19 de fevereiro de 1998. Altera, atualiza e consolida a legislação sobre direitos autorais e dá outras providências. Disponível em: <http://www.planalto.gov.br/ccivil_03/leis/L9610.htm>. Acesso em: 03 set. 2018. 

COMPLEXIDADES DOS CONTRATOS MULTINIVEL PRODUÇÃO, TRANSMISSÃO E SINDYCATION

meio do perfil do assinante, o conteúdo audiovisual encontra-se disponibilizado a um número irrestrito de pessoas, as quais o podem acessar de um número irrestrito de locais. Neste sentido, importante o entendimento do Ministro Ricardo Villas Bôas Cueva, para quem:

[...] a transmissão digital interativa, ou o "direito de colocar à disposição do público", ao fim e ao cabo, é um ato de execução pública, diretamente relacionado ao acesso às obras intelectuais disponibilizadas ao público via internet, que, como visto, é considerado local de frequência coletiva, ainda que ocorra no âmbito privado do usuário e que ausente a simultaneidade na recepção pelos destinatários.

Logo, o ordenamento jurídico pátrio consagrou o reconhecimento de um amplo direito de comunicação ao público, no qual a simples disponibilização da obra já qualifica o seu uso como uma execução pública, abrangendo, portanto, a transmissão digital interativa (art. 29, VII, da Lei $n^{\circ} 9.610 / 1998$ ) ou qualquer outra forma de transmissão ${ }^{54}$ (grifo do autor).

No entanto, há aqueles que defendem a tese de que, com base no Art. 30, caput, da $\operatorname{LDA}^{55}$, a simples disponibilização da obra ao público não configura execução de obra, mas sim reprodução de obra, não podendo, portanto, a disponibilização de obras por meio de streaming na modalidade webcasting ser considerada execução pública ${ }^{56}$. Neste sentido, foi o voto divergente do Ministro Marco Aurélio Bellizze, por ocasião do julgamento do RECURSO ESPECIAL $N^{\circ}$ 1.559.264 - RJ, oportunidade em que baseou seu ponto de vista no fato de que a plataforma de webcasting simplesmente disponibiliza as obras ao usuário, de forma a possibilitar que ele, usuário, escolha a obra que queira acessar, não se configurando, então, tal atividade econômica, como execução pública, mas sim como mera reprodução ${ }^{57}$.

Neste ponto, importante, salientar que a linha de raciocínio exposta no parágrafo anterior não se sustenta, pois, o Art. $30, \$ 2^{\circ}$, da LDA exige, no caso da reprodução, que a quantidade de exemplares seja informada e controlada, "[...] cabendo a quem reproduzir a obra

\footnotetext{
${ }^{54}$ BRASIL. Superior Tribunal de Justiça. Recurso Especial n 1.559.264 - RJ. Relator Ministro Ricardo Villas Bôas Cueva. Julgado em 08/02/2017. Disponível em: <https://ww2.stj.jus.br/processo/revista/documento/mediado/?componente=ITA\&sequencial=1518691\&n um_registro=201302654647\&data=20170215\&formato=PDF>. Acesso em: 15 jun. 2018.

${ }^{55}$ BRASIL. Lei $n^{\circ}$ 9.610, de 19 de fevereiro de 1998. Altera, atualiza e consolida a legislação sobre direitos autorais dá outras providências. Disponível em: <http://www.planalto.gov.br/ccivil_03/leis/L9610.htm>. Acesso em: 03 set. 2018.

${ }^{56}$ LOPES, Marcelo Frullani. STJ errou ao considerar streaming "execução pública". Revista Consultor Jurídico, São Paulo, nov. 2017. Disponível em: <https://www.conjur.com.br/2017-nov-28/marcelo-lopesstj-errou-considerar-streaming-execucao-publica\#_ftnref8>. Acesso em: 03 set. 2018.

${ }^{57}$ BRASIL. Superior Tribunal de Justiça. Recurso Especial $n^{\circ}$ 1.559.264 - RJ. Relator Ministro Ricardo Villas Bôas Cueva. Julgado em 08/02/2017. Disponível em: <https://ww2.stj.jus.br/processo/revista/documento/mediado/?componente=ITA\&sequencial=1518691\&n um_registro=201302654647\&data=20170215\&formato=PDF>. Acesso em: 15 jun. 2018.
} 

COMPLEXIDADES DOS CONTRATOS MULTINIVEL PRODUÇÃO, TRANSMISSÃO E SINDYCATION

a responsabilidade de manter os registros que permitam, ao autor, a fiscalização do aproveitamento econômico da exploração"58. O próprio Ministro Marco Aurélio Bellizze reconhece que "a realidade empírica revela que, muitas vezes, os próprios executores desconhecem quais serão as obras executadas" ${ }^{9}$, ora, se os próprios executores das obras audiovisuais desconhecem quais e quando as obras serão ou não executadas, claro está que eles não mantêm os registros que permitam, aos autores, a fiscalização do aproveitamento econômico da exploração, portanto, não há que se falar em mera reprodução de obra, pois, o requisito legal para a sua configuração, previsto no Art. $30, \S 2^{\circ}$, da $\operatorname{LDA}^{60}$, não se faz presente no caso da transmissão de obras audiovisuais, pela plataforma SVoD por streaming da espécie webcasting interativo.

Do cotejamento entre os dispositivos normativos e a interpretação judicial, pode-se entender que a transmissão de obras audiovisuais, pela plataforma SVoD por streaming da espécie webcasting interativo, trata-se de execução pública de obra audiovisual, exercida no âmbito do direito de comunição ao público, sendo, lícito ao ECAD e à eventual associação de autores e coautores de obras audiovisuais, desde que devidamente habilitada em Órgão da Administração Pública Federal, cobrar direitos autorais pela execução pública de tal conteúdo.

Tal cobrança deve ser realizada ao provedor, pois, é ele que proporciona a execução pública de obras audiovisuais e não o assinante, o qual apenas acessa o site para obter a prestação de serviço pela qual contratou. Assim decidiu o Ministro Ricardo Villas Bôas Cueva, ao tratar sobre a autorização de cobrança de direitos autorais pelo ECAD nas transmissões de conteúdos musicais via streaming, oportunidade na qual consignou em sua decisão que:

[...] a autorização de cobrança de direitos autorais pelo ECAD nas transmissões via streaming não se dá em decorrência do ato praticado pelo indivíduo que acessa o site, mas, sim, pelo ato do provedor que o mantém, disponibilizando a todos, ou seja, ao público em geral, o acesso ao conteúdo.

Portanto, considerando-se que, independentemente da existência dos critérios da interatividade, da simultaneidade na recepção do conteúdo e da pluralidade de pessoas, e que a internet é um local de frequência coletiva, a transmissão via

${ }^{58}$ BRASIL. Lei $\mathrm{n}^{\circ}$ 9.610, de 19 de fevereiro de 1998. Altera, atualiza e consolida a legislação sobre direitos autorais e dá outras providências. Disponível em: <http://www.planalto.gov.br/ccivil_03/leis/L9610.htm>. Acesso em: 03 set. 2018.

59 BRASIL. Superior Tribunal de Justiça. Recurso Especial $n^{\circ}$ 1.559.264 - RJ. Relator Ministro Ricardo Villas Bôas Cueva. Julgado em 08/02/2017. Disponível em: <https://ww2.stj.jus.br/processo/revista/documento/mediado/?componente=ITA\&sequencial=1518691\&n um_registro=201302654647\&data=20170215\&formato=PDF>. Acesso em: 15 jun. 2018.

60 BRASIL. Lei $\mathrm{n}^{\circ}$ 9.610, de 19 de fevereiro de 1998. Altera, atualiza e consolida a legislação sobre direitos autorais e dá outras providências. Disponível em: <http://www.planalto.gov.br/ccivil_03/leis/L9610.htm>. Acesso em: 03 set. 2018. 

COMPLEXIDADES DOS CONTRATOS MULTINIVEL PRODUÇÃO, TRANSMISSÃO E SINDYCATION

streaming é ato de execução pública, sendo legítima a arrecadação e distribuição dos direitos autorais pelo ECAD ${ }^{61}$.

Desta forma, revelando-se a transmissão de conteúdos audiovisuais, por meio de SVoD por streaming da espécie webcasting interativo, como execução pública, realizada no âmbito do direito de comunicação pública, de acordo com o contido no artigo $68, \$ 2^{\circ}$ e $3^{\circ}$, combinado com o artigo $5^{\circ}$, inciso V, da LDA, torna-se lícita, nos termos do artigo 86 e do artigo 97, caput, combinado com o artigo 98, caput e $\$ 1^{\circ}$, da $\operatorname{LDA}^{62}$, a cobrança dos direitos autorais, pela execução pública de conteúdo musical e de obras audiovisuais, pelo ECAD e por associação de autores e coautores de obras audiovisuais, esta última, desde que devidamente habilitada em Órgão da Administração Pública Federal.

Conforme já explanado, tais direitos autorais devem ser cobrados dos provedores que disponibilizam tais conteúdos ao público pela internet. Em virtude da inexistência de registros, que permitam aos autores a fiscalização do aproveitamento econômico da exploração das obras transmitidas, por meio de SVoD por streaming da espécie webcasting interativo, o Regulamento de Arrecadação do ECAD prevê que, quando o conteúdo principal transmitido via webcasting interativo for de obras audiovisuais, como é o caso da Netflix, o pagamento a ser realizado pelo provedor será de $2,55 \%$ da receita bruta do mês, sendo $1,77 \%$ a título de direitos autorias e $0,85 \%$ a título de direito conexo ${ }^{63}$, não havendo qualquer menção quanto à distribuição desses valores arrecadados aos autores e seus herdeiros, uma vez que, no Regulamento de Distribuição do $E C A D^{64}$ não há metodologia pré-definida para que os provedores, como a Netflix, façam o registro das transmissões de conteúdos audiovisuais, por meio de SVoD por streaming da espécie webcasting interativo, assim, não há metodologia pré-estabelecida para o envio de planilhas, contendo os dados de tais transmissões, ao ECAD, omissão que precisa ser rapidamente resolvida

61 BRASIL. Superior Tribunal de Justiça. Recurso Especial n 1.559.264 - RJ. Relator Ministro Ricardo Villas Bôas Cueva. Julgado em 08/02/2017. Disponível em: <https: / / ww2.stj.jus.br/processo/revista/documento/mediado/?componente=ITA\&sequencial=1518691\&n um_registro=201302654647\&data=20170215\&formato=PDF>. Acesso em: 15 jun. 2018.

62 BRASIL. Lei $n^{\circ}$ 9.610, de 19 de fevereiro de 1998. Altera, atualiza e consolida a legislação sobre direitos autorais dá outras providências. Disponível em: <http://www.planalto.gov.br/ccivil_03/leis/L9610.htm>. Acesso em: 03 set. 2018.

${ }^{63}$ ESCRITÓRIO CENTRAL DE ARRECADAÇÃO E DISTRIBUIÇÃO. Regulamento de Arrecadação. Rio de Janeiro: ECAD, 2015, p.32. Disponível em: <http://www.ecad.org.br/pt/eu-uso-musica/regulamento-dearrecadacao/Documents/Regulamento-da-Arrecadacao.pdf>. Acesso em: 03 set. 2018.

${ }^{64}$ ESCRITÓRIO CENTRAL DE ARRECADAÇÃO E DISTRIBUIÇÃO. Regulamento de Distribuição. Rio de Janeiro: ECAD, 2016. Disponível em: <http://www.ecad.org.br/pt/eu-faco-musica/Regulamento-deDistribuicao/Documents/Regulamento\%20Distribui\%C3\%A7\%C3\%A30_2016.pdf>. Acesso em: 03 set. 2018. 
por tal instituição privada, para que os valores por ela arrecadados possam ser adequadamente distribuídos aos titulares de direitos de autor e conexo.

\section{CONCLUSÃO}

A Netflix é a mais visível plataforma de Subscrition vídeo on demand - SVoD - por meio de streaming, da espécie webcasting interativo, da atualidade.

Todo o acervo audiovisual da Netflix é acessado sob demanda, ou seja, não há uma grade de horários para transmissão, o conteúdo começa a ser reproduzido logo que o usuário desejar.

O serviço é disponibilizado apenas para assinantes, os quais podem acessá-los por meio de uma conexão com a internet, desde que possuam o aplicativo do Netflix.

A demanda de seus clientes é identificada por meio da tendência de preferências de seus assinantes em cada região ou país, mensurada pela própria plataforma online e pelos taggers, cujo feedback orienta o conteúdo a ser produzido, visando a atender a demanda de seus clientes, estratégia que se revela como um diferencial no mercado audiovisual.

0 produto disponibilizado pela Netflix é de massa e ao mesmo tempo personalizado, pois, o que é disponibilizado à massa é direcionado pela plataforma online, de forma personalizada, aos assinantes, de acordo com suas interações com a plataforma.

O seu extenso acervo de conteúdos audiovisuais não foi construído por meio de uma simples análise de custo/benefício dos valores das licenças adquiridas dos estúdios, mas também por meio do monitoramento dos dados acerca dos conteúdos audiovisuais e de seus próprios assinantes, indicando, no mais das vezes, para a viabilidade de produções originais em detrimento da compra de licenças de produções independentes, visando evitar ou ao menos minimizar problemas relacionados à temporalidade e a geografia da distribuição, nacional e internacional, bem como problemas relacionados a direitos autorais.

A transmissão dos conteúdos audiovisuais pela Netflix dá-se por meio da prestação de serviço SVoD, realizado através de streaming de dados da espécie webcasting interativo, desta forma, o conteúdo disponibilizado aos seus clientes é o mesmo, no entanto, de acordo com o pacote assinado, básico, padrão ou premium, os assinantes terão acesso aos conteúdos com melhor qualidade de imagem e em mais de uma tela simultaneamente. 
ISSN 1981-3694

(DOI): $10.5902 / 1981369431802$

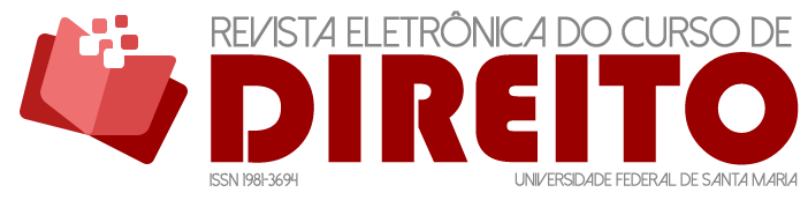

AVAILABILITY DE OBRAS NO NETFLIX E DIREITOS AUTORAIS: COMPLEXIDADES DOS CONTRATOS MULTINIVEL PRODUÇÃO, TRANSMISSÃO E SINDYCATION

EWERTON RICARDO MESSIAS JONATHAN BARROS VITA

Há limitações de acesso aos conteúdos audiovisuais de região para região ou de país para país, em virtude dos contratos de transmissão internacional - sindycation - firmados entre a Netflix e os estúdios de produção. Portanto, caso o estúdio não renove o contrato com a Netflix para determinada região ou país, após o término do período contratado, o conteúdo daquele estúdio deverá ser imediatamente bloqueado para os assinantes da Netflix naquela região ou país.

A Netflix vem enfrentando forte pressão em virtude de frequentes acessos por usuários de uma região ou país aos conteúdos audiovisuais de outras regiões ou países, os quais não estão disponibilizados a tais usuários. Para acessar os conteúdos não disponibilizados para sua região ou país, tais usuários utilizam programas de desbloqueio, fato que vem fomentando discussões sobre a jurisdição internacional e repercutindo no comércio internacional de produtos e serviços audiovisuais.

A relação estabelecida entre a Netflix e os assinantes de quaisquer de seus pacotes de serviços, trata-se de relação de consumo, visto que o próprio Termo de uso da Netflix, em seu item 4.2., prevê o assinante como destinatário final da prestação de serviço de acesso online aos conteúdos audiovisuais, enquadrando-se perfeitamente na definição de consumidor, prevista no artigo $2^{\circ}$, da Lei $n^{\circ} 8.078 / 1990$.

Desta forma, em relação às demandas litigiosas originadas de contratos multinível, envolvendo direitos e obrigações decorrentes de contratos de Transmissão e de sindycation de conteúdos audiovisuais firmados entre a Netflix e os estúdios de produção, inclusive no que se refere às invasões de conteúdos audiovisuais, compete à autoridade judiciária brasileira julgar ações judiciais decorrentes de demandas litigiosas relacionadas aos contratos de prestação de serviço firmados entre a Netflix e seus assinantes que tenham domicílio ou residência no Brasil., conforme interpretação do contido no artigo, 22, inciso II, da Lei nº 13.105/2015.

Para tais situações o Termo de uso do Netflix prevê a possibilidade de aplicações das penalidades de encerramento da conta ou restrição da utilização dos serviços, em virtude do fato de o usuário utilizar programas de desbloqueio para acessar o serviço Netflix.

No Brasil não há lei específica que regulamente a assinatura e os serviços de acesso online aos conteúdos audiovisuais, nem o Marco Civil da Internet, na forma da Lei $\mathrm{n}^{\circ}$ 12.965/2014, regulamenta tal assunto. Sendo uma relação de consumo, a relação estabelecida entre o Netflix e os assinantes de seus pacotes de serviços, de acordo com o artigo $4^{\circ}$, inciso III, da Lei $n^{\circ} 8.078 / 1990$, as penalidades previstas no Termo de uso do Netflix não se revelam 
ISSN 1981-3694

(DOI): $10.5902 / 1981369431802$

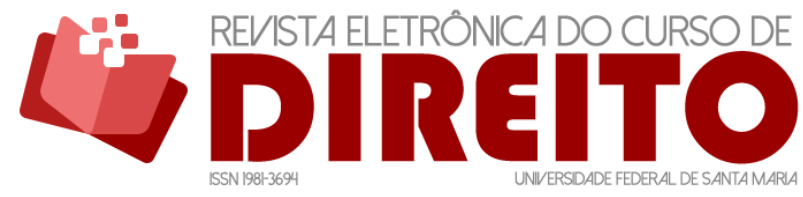

AVAILABILITY DE OBRAS NO NETFLIX E DIREITOS AUTORAIS: COMPLEXIDADES DOS CONTRATOS MULTINIVEL PRODUÇÃO, TRANSMISSÃO E SINDYCATION

EWERTON RICARDO MESSIAS JONATHAN BARROS VITA

abusivas ou ilegais, pois, baseadas no princípio da boa-fé objetiva, lastreada na confiança e na lealdade entre as partes contratantes, de forma a garantir o equilíbrio contratual.

Enquanto há evolução no acesso das pessoas à escolha de conteúdos audiovisuais em menor tempo, de onde quiserem e quando quiserem; a transmissão desses conteúdos sofre com a estagnação das normas que regem os contratos que a disciplinam, de forma a limitar temporal e geograficamente a transmissão dos conteúdos, fato que torna a globalização da prestação de serviços pela Netflix, ao menos por ora, um objetivo não alcançado, mas ainda a ser almejado.

A transmissão de conteúdos audiovisuais, por meio de SVoD por streaming da espécie webcasting interativo, revela-se como execução pública, realizada no âmbito do direito de comunicação pública, de acordo com o contido no artigo $68, \$ 2^{\circ}$ e $3^{\circ}$, combinado com o artigo $5^{\circ}$, inciso V, da LDA, assim, torna-se lícita, nos termos do artigo 86 e do artigo 97, caput, combinado com o artigo 98, caput e $\$ 1^{\circ}$, da LDA, a cobrança dos direitos autorais, pela execução pública de conteúdo musical e de obras audiovisuais, por associação de autores ou coautores de obras audiovisuais, desde que devidamente habilitada em Órgão da Administração Pública Federal, devendo, os direitos autorais, serem cobrados dos provedores que disponibilizam tais conteúdos ao público pela internet.

Por fim, conforme já explanado, os direitos autorais devem ser arrecadados pelo ECAD dos provedores que disponibilizam tais conteúdos ao público pela internet, devendo ser distribuída ao titular de direito de autor e conexo sua cota parte. Para tanto, urge que o ECAD desenvolva e insira em seu Regulamento de Distribuição uma metodologia apropriada para que os provedores, como a Netflix, façam o registro das transmissões de conteúdos audiovisuais transmitidos por meio de SVoD por streaming da espécie webcasting interativo, e enviem ao ECAD as planilhas contendo os dados de tais transmissões.

\section{REFERÊNCIAS}

ARAÚJO, Bruno. Netflix quer brasileiro para dar pegada local a cardápio de filmes e séries. Entrevista de Todd Yellin ao G1 São Paulo. Disponível em:

<http://g1.globo.com/tecnologia/noticia/2015/04/netflix-quer-brasileiro-para-dar-pegadalocal-cardapio-de-filmes-e-series.html>. Acesso em: 14 jun. 2018.

BITELLI, Marcos Alberto Sant'anna. 0 direito de autor e as obras audiovisuais. In: Revista do Centro de Estudos Judiciários, Brasília, n. 21, p. 40-44, abr./jun. 2003. 
BRASIL. Constituição da República Federativa do Brasil de 1988. Disponível em:

<http://www.planalto.gov.br/ccivil_03/constituicao/constituicaocompilado.htm>. Acesso em: 03. Set. 2018.

BRASIL. Lei $n^{\circ} \mathbf{8 . 0 7 8}$, de 11 de setembro de 1990. Dispõe sobre a proteção do consumidor e dá outras providências. Disponível em: <http://www.planalto.gov.br/ccivil_03/leis/L8078.htm>. Acesso em: 14 jun. 2018.

BRASIL. Lei $n^{\circ}$ 9.610, de 19 de fevereiro de 1998. Altera, atualiza e consolida a legislação sobre direitos autorais e dá outras providências. Disponível em:

<http://www.planalto.gov.br/ccivil_03/leis/L9610.htm>. Acesso em: 03 set. 2018.

BRASIL. Lei $\mathrm{n}^{\circ}$ 12.965, de 23 de abril de 2014. Estabelece princípios, garantias, direitos e deveres para o uso da Internet no Brasil. Disponível em:

<http://www.planalto.gov.br/ccivil_03/_ato2011-2014/2014/lei//12965.htm>. Acesso em: 15 jun. 2018.

BRASIL. Lei n 13.105, de 16 de março de 2015. Código de Processo Civil. Disponível em: <http://www.planalto.gov.br/ccivil_03/_ato2015-2018/2015/lei//13105.htm>. Acesso em: 15 jun. 2018.

BRASIL. Superior Tribunal de Justiça. Recurso Especial n 1.559.264 - RJ. Relator Ministro Ricardo Villas Bôas Cueva. Julgado em 08/02/2017. Disponível em:

<https://ww2.stj.jus.br/processo/revista/documento/mediado/?componente=ITA\&sequencial=1 518691\&num_registro=201302654647\&data=20170215\&formato=PDF>. Acesso em: 15 jun. 2018.

CARVALHO, Paulo de Barros. Direito Tributário, Linguagem e Método. $3^{\mathrm{a}}$ ed. São Paulo: Noeses, 2009.

CARVALHO, Paulo de Barros. Breves considerações sobre a função descritiva da Ciência do Direito Tributário. Disponível em: <http: / /www.conjur.com.br/2013-out-01/paulo-barrosbreves-consideracoes-funcao-descritiva-ciencia-direito-tributario>. Acesso em: 15 jun. 2018.

CARVALHO, Paulo de Barros. Constructivismo lógico-semântico. Disponível em: <https://enciclopediajuridica.pucsp.br/verbete/101/edicao-1/constructivismo-logicosemantico>. Acesso em: 14 jun. 2017.

CAVALIERI FILHO, Sergio. Programa de direito do consumidor. São Paulo: Atlas, 2009.

DIAS, Guilherme Ataíde; SOUSA, Rosilene Paiva Marinho de; PAIVA, Maria josé Rodrigues. Direito autoral e preservação digital: considerações pertinentes a periódicos científicos eletrônicos mantidos no sistema LOCKSS. Ciência da Informação, Brasília, v. 41 n. 1, p.92-102, jan./abr., 2012.

ESCRITÓRIO CENTRAL DE ARRECADAÇÃO E DISTRIBUIÇÃO. Regulamento de Arrecadação. Rio de Janeiro: ECAD, 2015. Disponível em: <http://www.ecad.org.br/pt/eu-uso-musica/regulamento-dearrecadacao/Documents/Regulamento-da-Arrecadacao.pdf>. Acesso em: 03 set. 2018. 
ESCRITÓRIO CENTRAL DE ARRECADAÇÃO E DISTRIBUIÇÃO. Regulamento de Distribuição. Rio de Janeiro: ECAD, 2016. Disponível em: <http://www.ecad.org.br/pt/eu-faco-musica/Regulamento-deDistribuicao/Documents/Regulamento\%20Distribui\%C3\%A7\%C3\%A3o_2016.pdf>. Acesso em: 03 set. 2018.

GALLAS, Daniel. Como a Netflix driblou a pirataria e fez do Brasil seu 'foguete'. Matéria publicada pela BBC Brasil. Disponível em:

<http://www.bbc.com/portuguese/noticias/2015/11/151123_netflix_pirataria_brasil_dg_fn>. Acesso em 14 jun. 2018.

HASTINGS, Reed. 'Brasileiros ainda não entenderam o Netflix', diz presidente da empresa. Matéria publicada pelo site G1. Disponível em:

<http://g1.globo.com/tecnologia/noticia/2012/08/brasileiros-ainda-nao-entenderam-o-netflixdiz-presidente-da-empresa.html>. Acesso em: 14 jun. 2018.

LADEIRA, João Martins. Negócios de audiovisual na internet: uma comparação entre Netflix, Hulu e iTunnes-AppleTV, 2005-2010. Revista Contracampo, Niterói, v. 26, n. 1, p.145-162, 2013.

LOPES, Marcelo Frullani. STJ errou ao considerar streaming "execução pública". Revista Consultor Jurídico, São Paulo, nov. 2017. Disponível em: <https://www.conjur.com.br/2017nov-28/marcelo-lopes-stj-errou-considerar-streaming-execucao-publica\#_ftnref8>. Acesso em: 03 set. 2018.

MILLS. Chris. Netflix está sob pressão para impedir acesso ao catálogo americano através de VPN. Disponível em: <http://gizmodo.uol.com.br/netflix-impedir-vpn/>. Acesso em: 14 jun. 2018.

NETFLIX Brasil. Planos de assinatura. Disponível em: <https://help. netflix.com/pt/node/412>. Acesso em: 14 jun. 2017.

NETFLIX Brasil. Termo de uso. Disponível em: <https://help.netflix.com/legal/termsofuse>. Acesso em: 14 jun. 2018.

PARLAMENTO EUROPEU. DIRECTIVA 2001/29/CE, de 22 de Maio de 2001. In: Jornal Oficial das Comunidades Européias, L 167/12, 22.06.2001. Disponível em: <http://eur-lex.europa.eu/legalcontent/PT/TXT/PDF/?uri=CELEX:32001L0029\&from=PT>. Acesso em: 16 jun. 2017.

PIRES, E; REIS, J.R. A utilização das Obras intelectuais Autorais Frente às novas Tecnologias: Função Social ou Pirataria?. Revista do Direito Unisc, Santa Cruz do Sul, v. 34, p. 27-40, 2010.

STIVALETTI, Thiago; LEITÃO, Gustavo. Novos caminhos do VoD - Explosão do video sob demanda no país amplia modelos de negócios e atrai competidores para as novas plataformas. Movimento também faz produtores repensarem suas estratégias de lançamento. Revista Filme $B+$, mar., 2016.

VILANOVA, Lourival. Fundamentos do Estado de Direito. In: Escritos Jurídicos e Filosóficos, vol. I. São Paulo: IBET/Axis-Mundi, 2008. 
ISSN 1981-3694

(DOI): $10.5902 / 1981369431802$

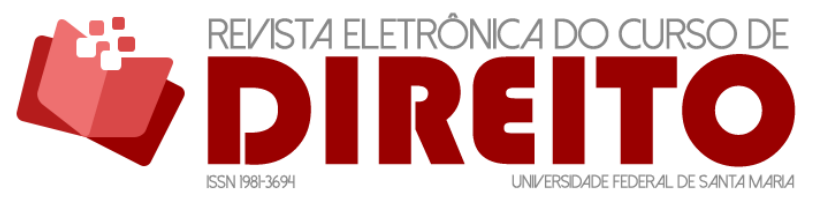

AVAILABILITY DE OBRAS NO NETFLIX E DIREITOS AUTORAIS: COMPLEXIDADES DOS CONTRATOS MULTINIVEL PRODUÇÃO, TRANSMISSÃO E SINDYCATION

EWERTON RICARDO MESSIAS JONATHAN BARROS VITA

VITA, Jonathan Barros. Valoração aduaneira e preços de transferência: pontos de conexão e distinções sistêmico-aplicativas. 2010. 927f. Tese de Doutorado - Pontifícia Universidade Católica. São Paulo. Disponível em:

<https: / sapientia.pucsp.br/bitstream/handle/5458/1/Jonathan\%20Barros\%20Vita.pdf>. Acesso em: 06 abr 2018.

Recebido em: 24.03.2018 / Revisões requeridas em: 30.08.2018 / Aprovado em: 25.10.2018 / Publicado em: 18.12.2018

\section{COMO FAZER A REFERÊNCIA DO ARTIGO (ABNT):}

MESSIAS, Ewerton Ricardo; VITA, Jonathan Barros. Availability de obras no Netflix e direitos autorais: complexidades dos contratos multinível - produção, transmissão e sindycation. Revista Eletrônica do Curso de Direito da UFSM, Santa Maria, RS, v. 13, n. 3, p. 1161-1189, dez. 2018. ISSN 1981-3694. Disponível em: <

https: //periodicos.ufsm.br/revistadireito/article/view/31802 >. Acesso em: dia mês. ano. doi: http://dx.doi.org/10.5902/1981369431802 . 